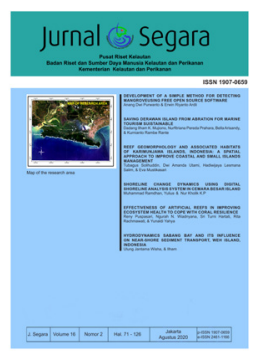

JURNAL SEGARA

http://ejournal-balitbang.kkp.go.id/index.php/segara

ISSN : 1907-0659

e-ISSN : 2461-1166

Nomor Akreditasi: 766/AU3/P2MI-LIPI/10/2016

\title{
REEF GEOMORPHOLOGY AND ASSOCIATED HABITATS OF KARIMUNJAWA ISLANDS, INDONESIA: A SPATIAL APPROACH TO IMPROVE COASTAL AND SMALL ISLANDS MANAGEMENT
}

\section{GEOMORFOLOGI TERUMBU KARANG DAN HABITAT TERKAIT KEPULAUAN KARIMUNJAWA, INDONESIA: PENDEKATAN SPASIAL UNTUK MENINGKATKAN PENGELOLAAN PESISIR DAN PULAU-PULAU KECIL}

\author{
Tubagus Solihuddin'1), Dwi Amanda Utami'2,3), Hadiwijaya Lesmana Salim¹), \& Eva Mustikasari'1) \\ 1)M1Marine Research Center, Ministry of Marine Affairs and Fisheries, Jakarta, Indonesia 14430 \\ ${ }^{2)}$ Research Center for Geotechnology, Indonesian Institute of Science, Bandung, Indonesia 40135 \\ ${ }^{3}$ Energy and Mineral Resources Group, Geologische Institute, RWTH Aachen University, Germany
}

Received: 11 December 2019; Revised: 22 Juni 2020; Accepted: 3 July 2020

\begin{abstract}
The Karimunjawa Islands are situated in the offshore of Jepara region of Central Java with abundant coastal and marine resources including coral reefs. The reef geomorphology appears typical of fringing reefs worldwide comprising reef flat, reef crest and reef slope. The reef geomorphic profiles are generally gently sloping seaward with slightly raised reef crest along the reef edge. The reefs slope moderately $\left(15-30^{\circ}\right)$ at the upper forereef slope ( $\sim-10 \mathrm{~m}$ depth) and tend to drop steeply, sometimes almost vertical, at depths of 10-30 m. The coral communities are found from the intertidal to a depth of about $15 \mathrm{~m}$, with the most vigorous development occurring between 1.5 to $5 \mathrm{~m}$. The reef flats have low coral cover and are extensively covered by a mixture of seagrass beds and carbonate sand. The reef crests, which mark boundaries between reef flat and upper forereef slope, are mainly colonized by mixed Acropora corals, mainly A. Hyacinthus. The forereef slopes have substantial coral growth prevailing mixed branching Acropora, Porites cylindrica and Porites sp. Sediments on the reef flats are mainly bioclastic materials derived from reef-erosion, including coral fragments, mollusks, foraminifera, red algae, Halimeda, Echinodermata, aggregate, quartz, and lithic fragments. Seagrass beds, mainly Enhalus, occur on the inner reef flat and are gradually shifted to macroalgae, predominantly Sargassum. The study provides a basic requirement for fisheries management and environmental monitoring for a mid-Sunda Shelf within a biodiversity "hotspot".
\end{abstract}

Keywords: Coral reef, geomorphology, benthic habitats, management, environmental monitoring, Karimunjawa.

\section{ABSTRAK}

Kepulauan Karimunjawa terletak di lepas pantai Jepara Jawa Tengah dengan sumber daya pesisir dan laut yang melimpah termasuk terumbu karang. Geomorfologi terumbu karang menunjukkan ciri khas terumbu karang tepi yang berlaku di seluruh dunia terdiri dari rataan terumbu, puncak terumbu, dan lereng terumbu. Profil geomorfologi terumbu umumnya landai ke arah laut dengan puncak terumbu yang agak tinggi di sepanjang tepi terumbu. Kemiringan terumbu sedang (15-30 $)$ pada bagian lereng terumbu (kedalaman 5-10 m) dan cenderung menurun dengan curam, bahkan hampir vertikal, pada kedalaman 10-30 m. Komunitas karang hidup terdapat pada zona intertidal hingga kedalaman sekitar $15 \mathrm{~m}$, dengan densitas paling tinggi terdapat pada kedalaman antara 1,5 hingga $5 \mathrm{~m}$. Rataan terumbu memiliki tutupan karang yang rendah dan didominasi oleh campuran padang lamun dan pasir karbonat. Puncak terumbu, yang menandai batas antara rataan terumbu dan lereng terumbu, sebagian besar ditumbuhi koloni Acropora, terutama A. Hyacinthus. Lereng terumbu bagian depan memiliki pertumbuhan yang cukup tinggi didominasi oleh karang jenis Acropora, Porites cylindrica dan Porites sp. Sedimen di rataan terumbu sebagian besar merupakan sedimen bioklastik yang berasal dari erosi terumbu, termasuk fragmen karang, moluska, foraminifera, alga merah, Halimeda, Echinodermata, agregat, kuarsa dan fragmen litik. Hamparan padang lamun, terutama

Corresponding author:

Jl. Pasir Putih I Ancol Timur, Jakarta Utara 14430. Email: solihuddin@gmail.com 
Enhalus, terdapat di rataan terumbu bagian dalam dan secara bertahap beralih ke makroalga, terutama Sargassum. Studi ini memberikan dasar pertimbangan dalam pengelolaan perikanan dan pemantauan lingkungan di wilayah Paparan Sunda dengan karakteristik keanekaragaman hayati yang melimpah.

Kata kunci: Terumbu karang, geomorfologi, habitat bentik, pengelolaan, pemantauan lingkungan, Karimunjawa.

\section{INTRODUCTION}

Sitting in a biodiversity "hotspot" of the mid-Sunda Shelf, the Karimunjawa Islands (Figure. 1) have abundant coastal and marine resources including coral reefs which provide important biological, ecological, and economic functions. The islands have currently been the priority for marine biodiversity conservation as a consequence of Marine Protected Areas (MPAs). The concern to protect the high marine biodiversity and natural resources of the region and to monitor the development of the Karimunjawa Islands have been outlined and highlighted on the national document of marine conservation zone management and planning (Solihuddin et al., 2109).

The islands have already been utilized for commercial activities such as marine tourism, fishing ground, aquaculture, and port facilities, besides traditional use by the local people. Despite the fact that current uses have only resulted in limited anthropogenic disturbance, extensive marine tourism growth over the coming years will likely disrupt the marine environment considerably. Accordingly, the threats from the climaterelated changes such as sea surface temperature rise, ocean acidification, and predicted increases in the intensity of storm surges needs to be urgently assessed and monitored to enable researchers and managers to accurately measure and document changes over time (Kordi \& O'Leary, 2016).

Until recently, there have been only few studies of substrates and habitats mapping from a geomorphological perspective in Indonesia (Solihuddin et al., 2019), despite the fact that Indonesian Archipelago contains some of the most diverse of island groups across the globe (Kuenen, 1933). Study of coral reefs has been focused on ecological studies with very limited studies linked to an understanding of reef geomorphology and coastal geology. On the other hand, there is a need to better understand of reef geomorphology and associated substrates and their use in developing and implementing management and conservation policies (Asriningrum, 2011, Madden et al., 2013). Recent work by Solihuddin et al. (2019) highlighted the need for further geomorphic studies of the Karimunjawa reefs and their accretion history.

The zonation of reef geomorphology provides significant information relevant to substrates present, coral communities, and benthic habitats which represent a major control on biological diversity
(Freeman \& Rogers, 2003). Such information gives a foundation for long-term coral reef studies and environmental monitoring that should be taken into consideration when planning and managing sustainable Karimunjawa marine and coastal resources.

\section{Reef remote sensing}

Application of satellite-based remote sensing on marine environmental and ecological properties such as Sea Surface Temperature (SST), chlorophyll-a, Total Suspended Sediment (TSS), precipitation, solar radiation, salinity, algal blooms, coral reef and sediment facies has been broadly used as reconnaissance and practical tools (Lyzenga, 1981; Ahmad \& Neil, 1994; Mumby et al., 1998; Gischler \& Lomando, 1999; Maedar et al., 2002; Rankey, 2002; Purkis \& Pasterkamp, 2004; Purkis et al., 2005; Riegl et al., 2007; Harris \& Vlaswinkel, 2008; Harris et al., 2010; Kaczmarek et al., 2010; Madden et al., 2013; Kordi \& O'Leary, 2016, and many others). However, very few studies have been globally undertaken on reef geomorphic and associated substrates (Hopley \& Partain, 1986; Blanchon et al., 1997; Kennedy \& Woodruffe, 2002, Purkis et al., 2012; Madden et al., 2013).

Reef geomorphic zones (e.g. forereef, reef crest, reef flat, back reef, lagoon) and associated substrates or benthic habitats (e.g. coral, marine fauna, marine flora, rubble, sediment) are closely related to the depth distributions and benthic community structures (Stoddart, 1969) which spatially occur at scales of tens to hundreds of meters, so that they are mappable and measurable by both passive (e.g. satellite) and active sensors (e.g. radar). Since reef build-up flourishes in clear and optically shallow water ( $<30 \mathrm{~m}$ depth), these environmental conditions are ideal for passive remote sensors to measure the electromagnetic radiance from the sun reflected from submerged coral reefs. The moderate- (e.g. Landsat MS, TM, ETM+; SPOT-HRV; ASTER) and high-resolution sensors (e.g. IKONOS, Quickbird) enable rapid and cost-effective mapping of coral reef systems at multiple scales and significantly improve the science needed for an effective and efficient management (Mumby et al., 1998).

Currently, satellite-based remote sensing has been broadly utilized in many purposes and further implemented on coral reef areas around the globe (e.g. Phillipines: Bina, 1982; India: Deshmukh et al., 2005; Dominican Republic: Luczkovich et al., 1993; Singapore: Sanderson, 2001) with some improvement 
both spatial and spectral resolution. Kutser et al., (2003) demonstrated that Landat (TM or ETM+), SPOT HRV or ASTER can differentiate 3 to 6 subtidal habitat types (e.g. coral reef, seagrass, sand, hard substrate) with reasonable accuracy $(60-75 \%)$.

Since on ground observations are usually very time-consuming and prohibitively expensive to be conducted over a large area and time series data acquisition, remote sensing technology with limited ground truthground truth offers the most rapid and cost-effective approach to observe and characterize an entire region of reefs without relying on sampling and extrapolation (Andréfouët et al., 2006). Here, the integration of multispectral bands of Landsat8 imagery supported by ground truth observations was employed to provide a satellite-based reef geomorphic zone and associated benthic habitats of selected islands in the Karimunjawa Islands, including Karimunjawa, Kemujan, and Menjangan Islands. The study will provide a suitable knowledge base within which assessments can be made by coastal planner and managers for conservation policies and MPA planning. This should allow regional managers to more optimally and efficiently allocate their resources to monitoring and protecting different areas within the great expanse of the Indonesian region.

\section{METHODOLOGY}

\section{Study Area}

The Karimunjawa Islands are located at about 80 $\mathrm{km}$ northwest of Jepara, consisting of 27 islands with a total land area of about $78 \mathrm{~km}^{2}$ (Figure 1). The Karimunjawa and Kemujan are two largest islands with an area of 2,700 ha and 1,400 ha respectively. The islands are significantly influenced by the monsoonal climate prevailing easterly flow of surface current during the northeast monsoon from November to March. The pattern is reversed and the surface waters of the Java Sea are westerly flow during the southeast monsoon from May to September (Gordon et al., 2003; Wyrtki, 1961). This monsoonal reversal of surface currents is responsible for major changes in sea surface salinities ranging from $31 \mathrm{PSU}$ during the northeast monsoon to 35 PSU during the southeast monsoon. The bathymetry of the region is relatively shallow, rarely exceeding $55 \mathrm{~m}$ depth. The Karimunjawa Islands are pre-Tertiary continental island consisting predominantly of quartzites and shales covered by basaltic lava. The island chains are part of Sundaland consisting mainly of erosional crystalline schists sediments from the Upper-Triassic flysch formation of Sundaland (van Bammelen, 1949).

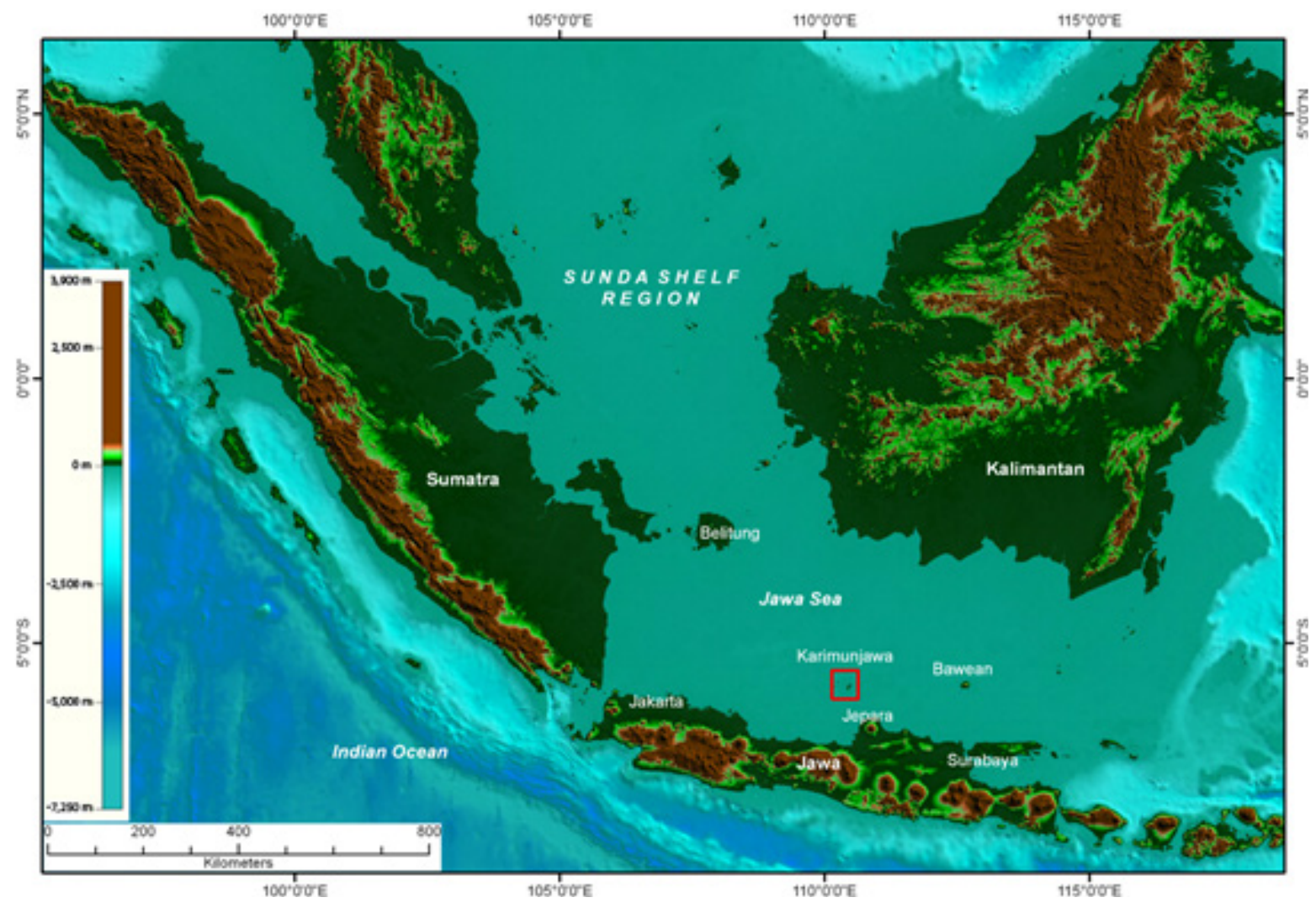

Figure 1. Map of study location and adjacent areas showing Karimunjawa Islands in the mid-Sunda Shelf. (Basemap: Gebco 0.8 grid with a spatial resolution of 30 arc-second of latitude and longitude. Data processing in 2019 ). 


\section{Satellite image and processing}

The study was based on a Landsat 8 OLI multispectral satellite imagery scene (path 120, row 064) acquisition date on 8th January 2017, downloaded from the United State Geological Survey (USGS) Earth Resources Observation and Science Data Centre (www.earthexplorer.usgs; accessed in 2017). Despite the moderate spatial resolution $(\sim 30 \mathrm{~m})$ of Landsat sensors, it has a long term archive that was accessible at no cost, enabling images selection that were acquired close enough to the field observation dates. The scenes were selected according to the best available visibility and relatively clear waters. The reefs were selected because of the priority marine biodiversity conservation and the availability of ground truth data.

The images were corrected geometrically using a geographic coordinate system and WGS 84 reference datum. A simplified workflow of hand digitizing technique from Harris \& Vlaswinkel (2008) was applied to delineate reef geomorphic zones, while the three visible bands of Landsat8, i.e. band $2(0.45-0.52 \mu \mathrm{m}$; blue), band 3 ( $0.52-0.60 \mu \mathrm{m}$; green) and band 4 ( 0.63 $-0.68 \mu \mathrm{m}$; red) supported by ground truth checking were employed to produce a Landsat-derived reef substrates and habitats map following a procedure of shallow water mapping described in Lyzenga (1981). This simple method uses the ratio of a pair of waterpenetrating bands to remove water column depth effects on reflectance by effectively creating a depth invariant bottom index.

Areas that were not of interest for mapping purposes were masked to reduce the variability of spectral classes (Kaczmarek et al., 2010; Madden et al., 2013). Following this, a digital unsupervised classification from ERDAS' ER Mapper utility was then used to define reef substrate and habitat zones, and save as vector files. Polygons from each reef habitats are imported as shapefiles into ArcGIS. Where present, overlap between polygons is removed and polygons are merged and corrected. On ground observations of reef substrates and habitats were assigned to the overlying Landsat image pixels (each pixel captures a 900 square meter area). All pixels with similar spectral characteristics were then automatically assigned to that defined habitat.

\section{Reef transect and sampling}

Contemporary reef habitats were investigated along the transect sites which were generally oriented perpendicular to the trend of the shoreline. Visual assessment and description were the first stage to obtain information on modern reef communities such as substrates, biota types and coral taxonomy to the extent possible. The generic coral identification was following Veron's nomenclature (Veron, 2000). Due to the difficulty of producing accurate species-level determinations, living coral communities were compared at the genus level. Fifty sediment samples were collected as necessary from a subset of the nine transect lines for sediment composition in 2017. Sedimentary environment was mapped by Solihuddin et al. (2019) using triangular diagram classification proposed by Folk (1954) for sediment texture, grain mounts of microscopic characterization (cf. Mazzullo et al., 1988) for sediment composition and a modified version of the carbonate rock classification scheme from Dunham (1962) for sediment carbonate facies. Ground truth and sampling locations were photographed and recorded with a built-in camera-global positioning system (GPS) unit with relatively high accuracy $\pm 2 \mathrm{~m}$.

\section{Accuracy assessment}

To quantify the extent to which the modern benthic habitats are represented in Landsat-derived reef geomorphology and associated habitats map, a metric called "overall accuracy" (Mumby et al., 1998) was calculated, reflecting the overall agreement in the map as determined by a point of count of correctly classified pixels. Overall accuracy $(\%)=$ (number of correctly classified pixels/total number of geomorphic zones) ${ }^{\star} 100$. Results of the "overall accuracy" metrics give an indication that the pixels of the classified Landsat image represent the habitats on the ground, as determined from field observation and sampling (Kaczmarek et al., 2010).

\section{RESULTS AND DISCUSSION}

Below we summaries' the reef geomorphology and associated habitats of the three study sites: Karimunjawa, Kemujan, Menjangan Islands. A map of reef geomorphology provides a broad characterization of reef geomorphic zones in which significant information related to habitat present is indicated (Figure 2a). Landsat image interpretation linked to the reef transects allows delineating of four benthic habitat zones, including: 1) sand flat, 2) seagrass bed, 3) mixed seagrass beds and sand, and 4) coral in which general patterns and characteristics of benthic communities distribution are recognized (Figure 2b). The detailed descriptions of the three different study sites are provided.

\section{Karimunjawa Island}

The rock outcrops of Karimunjawa Island are Pre-Tertiary quartz sandstone, micaceous sandstone, quartz conglomerate, quartz siltstone and quartz shale of Karimunjawa Formation (Sidarto et al., 1993). The island topography is relatively high, rising to a maximum elevation of $510 \mathrm{~m}$ above MSL based on shuttle radar topography mission (SRTM) data (http:// dds.cr.usgs.gov/srtm/). The intertidal beach is generally narrow $( \pm 15 \mathrm{~m})$ and short $( \pm 50 \mathrm{~m})$ and developed on the sheltered embayment beaches across the island, 

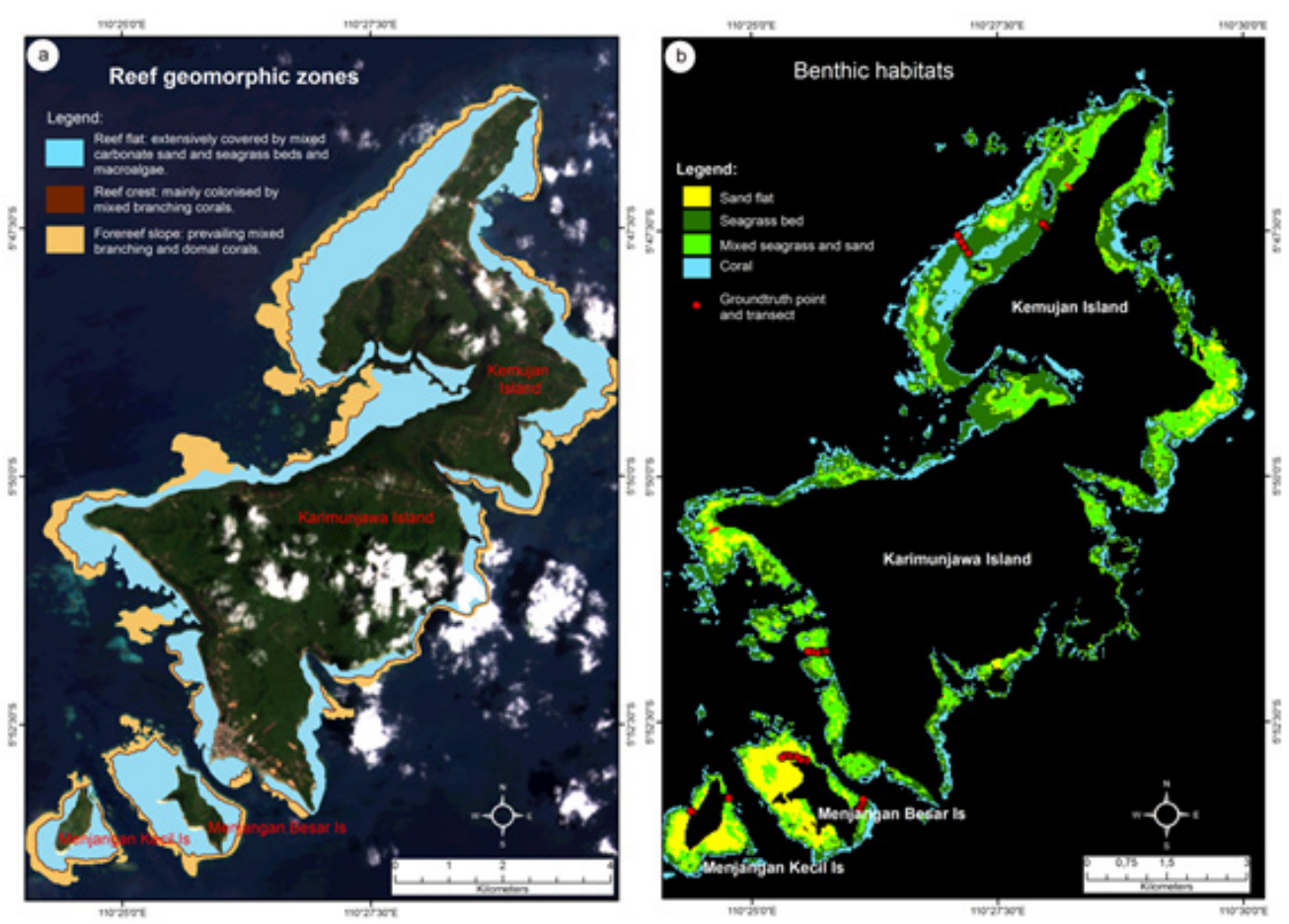

Figure 2. Map of study location and adjacent areas showing Karimunjawa Islands in the mid-Sunda Shelf. (Basemap: Gebco 0.8 grid with a spatial resolution of 30 arc-second of latitude and longitude. Data processing in 2019 ).

consisting of coarse terrigenous sand, coral debris, shells, and gastropods. The boulder rubble zones stretch along the base of rocky cliff sections of the east side of Karimunjawa Island and consist mainly of quartz sandstone.

The two transect lines on the west side of Karimunjawa Island around Tanjung Gelam and Mangrove Inn show that the reef geomorphic profiles are gently sloping seaward with slightly raised reef crest along the reef edge. The reefs slope moderately beyond the crest with an approximate slope of $30^{\circ}$ and constantly down to a depth of $25 \mathrm{~m}$. The seagrass beds, mainly Enhalus, are widely distributed on the nearshore of Karimunjawa Island until around $50 \mathrm{~m}$ from the shoreline, resting on carbonate sand substrates. Macroalgal-covered carbonate sand substrates are also frequently found on the inner reef flat, moving seaward from the seagrass beds. Sediments on the reef flat are coarse carbonate sand with in estimated order of abundace: coral (56\%), mollusks (34\%), Halimeda (4\%), foraminifera (4\%), Echinodermata $(1 \%)$, red algae $(1 \%)$ and aggregate $(<1 \%)$. Extensive distribution of mixed branching Acropora, mainly $\mathrm{A}$. hyacinthus, occurs on the reef crest (Figure. 3a) along with small colonies ( $<0.5 \mathrm{~m}$ in diameter) of Platygra (Figure. $3 b$ ) and many other coral genera including plate Acropora and Montipora. High coral cover of Porites cylindrica, Porites sp and branching Acropora colonizes the forereef slope which moderately sloping down in the upper $5 \mathrm{~m}$ of the slope (Figure. 3c).

\section{Kemujan Island}

Kemujan Island is on the north separated from Karimunjawa Island by mangrove-fringed narrow channel. The rock outcrops of the island are volcanic and sedimentary rocks, consisting of Pliocene volcanic breccia, tuff and lavas of Parang Formation and PreTertiary rocks of Karimunjawa Formation (Sidarto et al., 1993). The maximum elevation of the island is $75 \mathrm{~m}$ above MSL based on SRTM data. The intertidal beach is generally narrow $( \pm 15 \mathrm{~m})$ and developed along the beach sections of Kemujan Island, consisting of coarse sand and various detrital elements derived from reef communities such as coral fragments, shells, and foraminifera.

The three transect lines on the west side of Kemujan Island show that the reef geomorphic profiles are generally gently sloping seaward with almost no raised reef crest on the reef edge. The reefs slope moderately $\left(30^{\circ}\right)$ at the upper forereef slope ( 5-10 $\mathrm{m}$ depth) and tend to drop steeply, sometimes almost vertical, at depths of 10-30 m. Seagrass beds, mainly Enhalus, are abundant in the nearshore, resting on carbonate sand substrates with an approximate density of $40 \%$. Moving seaward, the seagrass density is gradually decreasing and shifted to macroalgae, mainly Sargassum (Figure. 4a). Sediments on the reef flat are predominantly coarse carbonate sand 

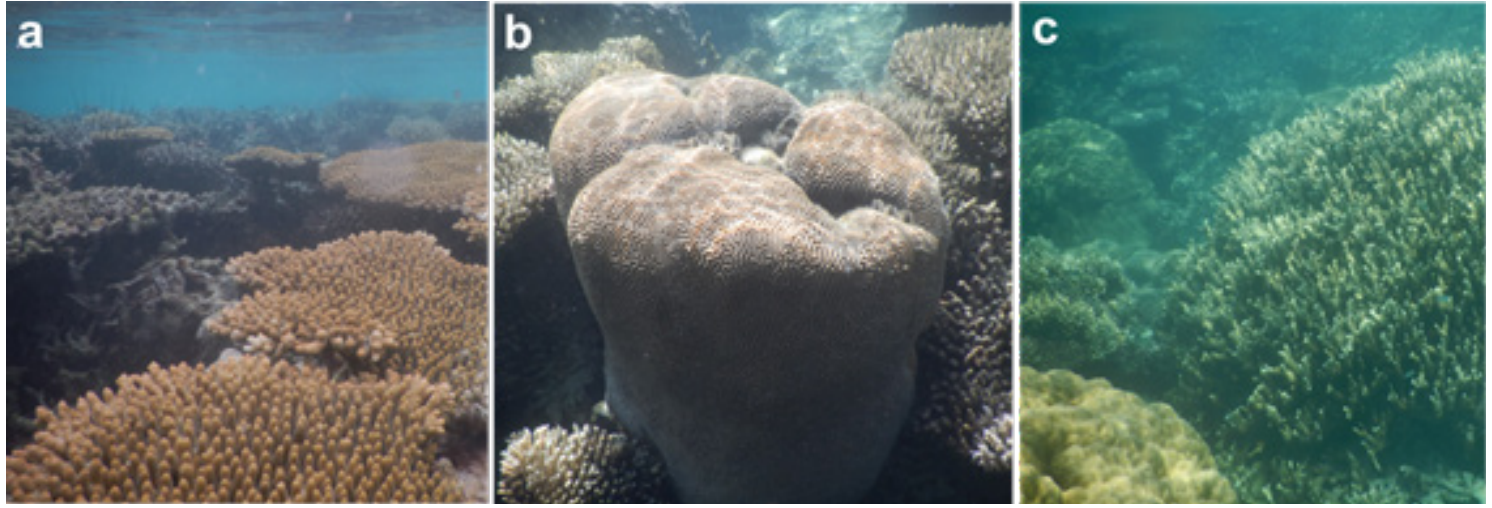

Figure 3. Living coral communities of the Karimunjawa Island reef showing (a) extensive mixed branching Acropora, mainly A. Hyacinthus, on the reef crest, (b) colonies of Platygra, plate Acropora and Montipora on the reef crest, and (c) high coral cover of Porites cylindrica, Porites sp and branching Acropora on the forereef slope.

with in estimated order of abundance: coral $(31 \%)$, mollusks $(28 \%)$, quartz $(17 \%)$, rock fragments $(10 \%)$, foraminifera $(6 \%)$, Halimeda $(4 \%)$, red algae $(2 \%)$, Echinodermata (1\%) and aggregate (1\%). Living corals from the genera of Acropora nasuta, Acropora formosa and Porites $s p$ are also frequently found on the reef crest (Figure $4 \mathrm{~b})$. Individual colonies of Porites $s p( \pm 1$ $\mathrm{m}$ in diameter) are main coral species on the forereef slope which drops down steeply in the middle to the lower-most of the slope (Figure 4c).

\section{Menjangan Islands}

Menjangan Islands comprise two islands i.e. Menjangan Besar and Menjangan Kecil. They are situated 0.5 and $2 \mathrm{Km}$ southwest of Karimunjawa Island respectively. A 15-20 m deep narrow channel separates Menjangan Besar Island from the Karimunjawa Island. The islands are small elongate-shape platform reefs with vegetated sand cay in the center surrounded by a wide intertidal reef platform. The cays are mainly bioclastic materials derived from reef-erosion, including coral fragments, mollusks, foraminifera and algae.
The Pre-Tertiary rocks of Karimunjawa Formation outcrops locally at the southern end of the Menjangan Besar Island. Based on reef transects, the geomorphic profiles are generally gently sloping seaward until the reef edge ( 50-100 $\mathrm{m}$ from the shoreline) and the reef front slopes seaward at approximately $15^{\circ}$ at $\sim 2 \mathrm{~m}$ deep and abruptly end at $\sim 30 \mathrm{~m}$ deep where the coral gives way to a seabed of moderate to coarse carbonate sand.

At Menjangan Besar Island, living corals are sparsely distributed on the inner reef flat which is more characterized by extensive sand flats. The seagrass beds, mainly Enhalus, are widely distributed on the west side of Menjangan Besar Island with an approximate density of $40-60 \%$, resting on the carbonate sand substrates (Fig. 5a). Sediment composition includes, in estimated order of abundance: coral $(56 \%)$, mollusks $(33 \%)$, red algae $(4 \%)$, foraminifera $(3 \%)$, Halimeda $(1 \%)$, rock fragments $(1 \%)$, Echinodermata $(1 \%)$ and minor aggregate. Microatolls were also frequently found in the intertidal reef flat $( \pm 1 \mathrm{~m}$ in width) mainly from the genera of Porites $s p$ (Figure $5 b$ ). The forereef slopes
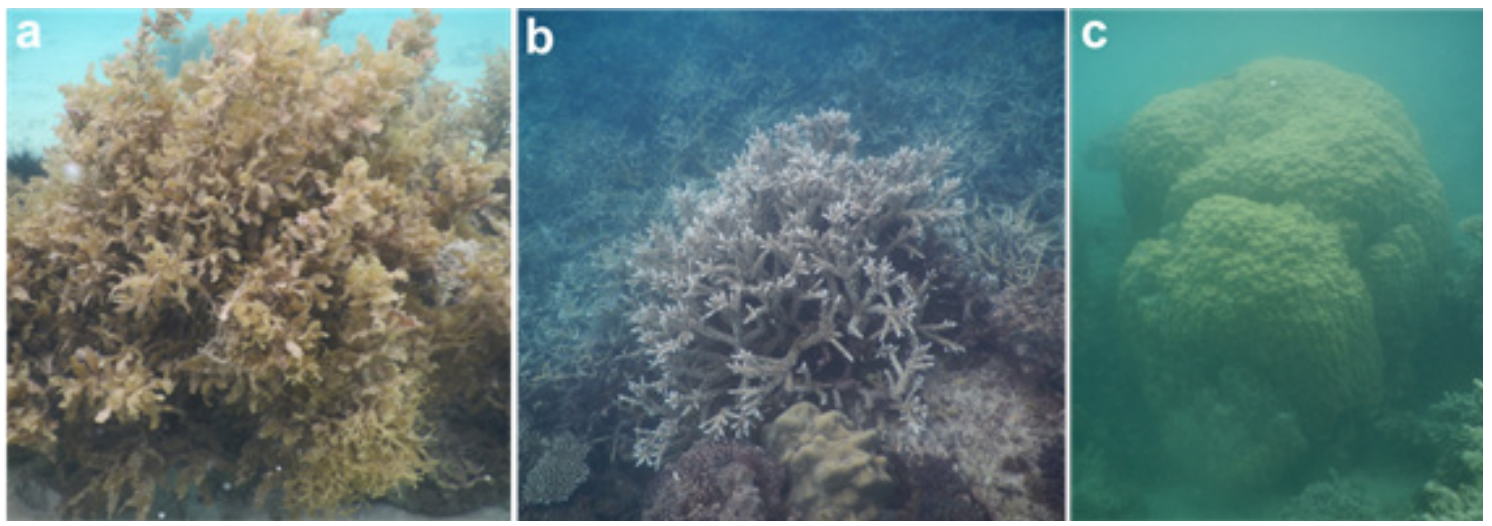

Figure 4. Contemporary reef habitats of Kemujan Island showing (a) Sargassum on carbonate sand substrates, (b) extensive living corals of mixed branching Acropora on the reef crest, and (c) individual colonies of Porites sp on the forereef slope. 

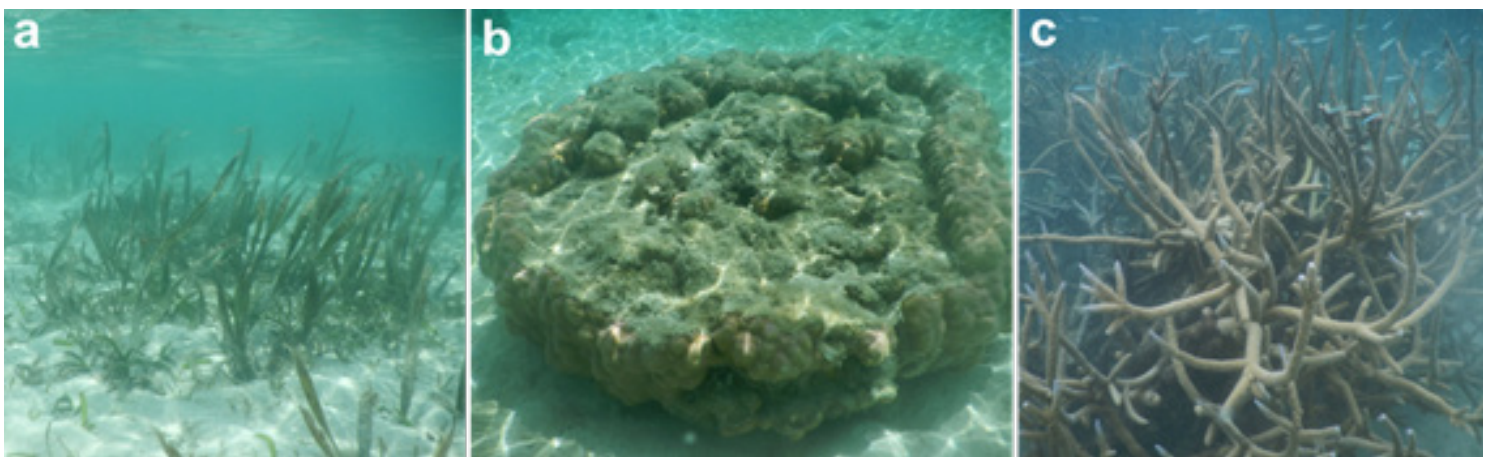

Figure 5.

Contemporary reef habitats of Menjangan Besar Island showing (a) seagrass beds of Enhalus with minor Thalassia resting on carbonate sand substrates, (b) colonies of Porites microatolls on the intertidal reef flat, and (c) prolific growth of Acropora formosa on the forereef slope.

have substantial coral growth with prolific branching Acropora formosa growth (Figure 5c).

At Menjangan Kecil Island, the seagrass beds, mainly Thalassia, are distributed around $10-40 \%$ densities on the inner reef flat. The intertidal sand flats, derived mainly from coral fragments $(58 \%)$, mollusks $(31 \%)$ often with minor Halimeda, red algae and foraminifera, extensively occupy the inner reef flat which has low coral cover. Branching Acropora grandis along with many other plate corals from the genera of Acropora and Montipora (Figure 6a) and Turbinaria (Figure 6b) extensively occur on the reef crest. Prolific growth of massive Porites $s p$ and branching Porites cylindrica occurs on the forereef slope (Figure 6c).

\section{Overall accuracy}

Four classes of benthic habitats were identified in four intra-reef geomorphic zones including two reef types (fringing and planar). Overall accuracy using a confusion matrix process was applied and ranged between $60 \%$ and $66 \%$, reflecting the overall agreement in the map as determined by a point of count of correctly classified pixels (Table 1). The map consists of substrate and habitat classification maps with latitude and longitude grid and a scale bar, a map legend showing map features based on geomorphic zones, and a geomorphic zones map showing the intra-reef geomorphic units of the reef platform. Each geomorphic unit is presented in a different colour on the platform.

\section{Reef characteristics of the Karimunjawa Islands}

Reefs formed and developed in the Karimunjawa Islands in the form of either fringing or platform reefs have a high abundance and diversity of corals. However, up to now only cursory surveys of the reefs have been conducted. According to unpublished surveys conducted by Diponegoro University, Semarang, there are at least 29 scleractinian genera belonging to 12 families. This is most likely an underestimate abundance, since reliable information on species distribution within the island chain is not available. By comparison, we propose the coral communities based on our field observations, including, in estimated order of abundance: tabular and fine arborescent forms of Acropora (i.e. A. formosa, A. hyacinthus, A. grandis, A. nasuta, A. palifera), Porites cylindrica, Porites sp, Turbinaria, Favia, Montipora sp, Favites, Goniopora, Lobophyllia, Symphyllia, Astreopora, Montipora digitata,
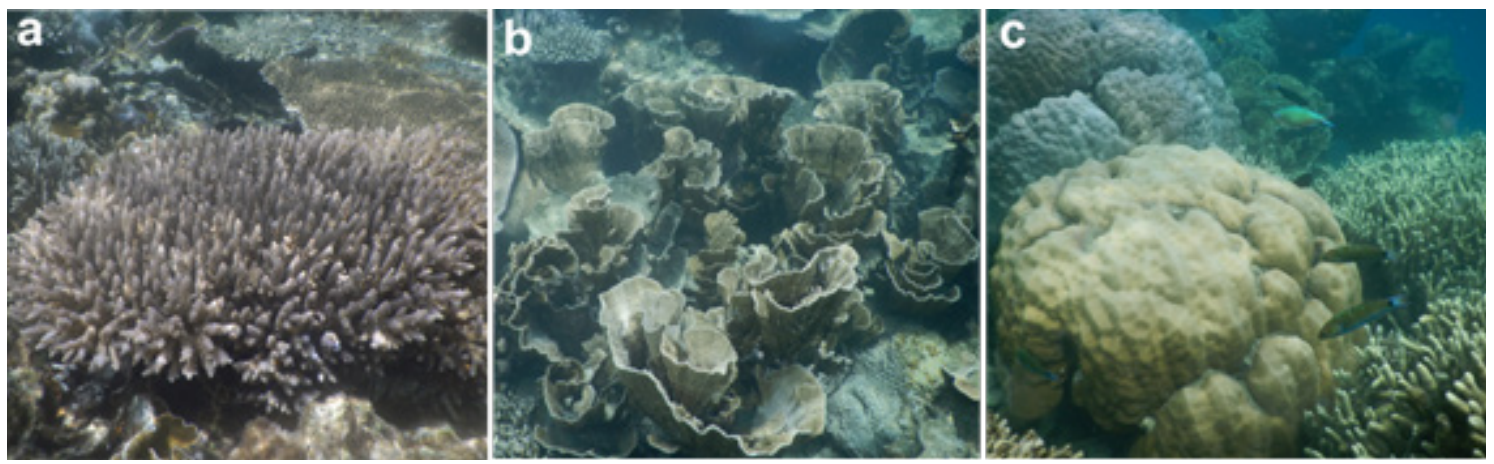

Figure 6. Contemporary reef habitats of Menjangan Kecil Island showing (a) branching Acropora grandis along with plate coral on the reef crest, (b) colonies of Turbinaria on the reef crest, and (c) prolific growth of massive Porites $s p$ and branching Porites cylindrica on the forereef slope. 
Table 1.

The overall accuracy of each reef by classes. Overall accuracies have been broken down into individual accuracies of each habitat and substrate

\begin{tabular}{|c|c|c|c|c|c|}
\hline \multirow[t]{2}{*}{ Reef } & \multicolumn{4}{|c|}{ Classes (\%) } & \multirow[t]{2}{*}{ Overall Accuracy } \\
\hline & SF & SB & MSS & CR & \\
\hline Karimunjawa Island & 17,0 & 18,6 & 15,6 & 9,4 & $60,6 \%$ \\
\hline Kemujan Island & 18,3 & 17,5 & 18,7 & 11,6 & $66,1 \%$ \\
\hline Menjangan Islands & 19,5 & 18,2 & 11,2 & 12,3 & $61,2 \%$ \\
\hline
\end{tabular}

Note: Description of substrate and habitat classes abbreviations: 'SF = sand flat; 'SB= seagrass bed; 'MSS' = mixed seagrass and sand; 'CR' = coral reef.

Echinopora, Goniastrea, Cyphastrea, Galaxea, Fungia, Favona, Psammocora and Stylophora. This information of seabed benthic environments is a basic requirement for fisheries management and environmental monitoring (Diaz et al., 2004).

The community structure of reef-associated organism shares similarities to the "arborescent coral facies" description in Montaggioni's Indo-Pacific reef classification scheme (2005). It differs from the typical arborescent coral reef in a respect of live branching corals on the contemporary Karimunjawa Islands reef occur on the upper forereef slope between 1.5 to 5 $\mathrm{m}$ deep. Whereas on the other Indo-Pacific reefs, it typically occurs on the lower to middle parts of forereef zones, inner reef flats and nearby backreef slopes (Montaggioni, 2005; Hopley, 2007).

Based on basic division of Indonesian fringing reefs from Tomascik et al. (1997), the Karimunjawa fringing reefs fall into the reefs attached to high continental island reef, demonstrating several characteristics, including 1) developed over the rocky slopes of the islands, 2) narrower reef flat on the windward side (exposed reefs) than those on the leeward side (sheltered reefs), 3) moderately-sloping reefs $\left(15-30^{\circ}\right)$ on the upper forereef slope and tend to drop steeply, approaching vertical, on the middle to lower-most of forereef slope. What interesting is, based on information from bathymetric profile, the steep drop-off of the forereef slope of Karimunjawa fringing reefs occurs both on the leeward and windward sides. Unfortunately, the other high continental island reefs in addition to Karimunjawa, i.e. Bawean on the north off of Surabaya and Belitung on the east coast of Sumatra (Figure. 1), have currently less availability of quantitative information to make a meaningful comparison.

\section{Challenges of using remote sensing for reef mapping}

Despite the fact that remote sensing techniques offer the most rapid and cost-effective approach to observe and characterize a large area of reef environments, the spatial and spectral variability of the reef environments limit the transferability and accuracy of detailed coral reef mapping accomplished via Landsat imagery in this study. The study shows that the Landsat image can effectively be used to map the geomorphology of coral reef by applying image analysis technique and using unsupervised classification. An overall accuracy of between $60-66 \%$ was obtained using a confusion matrix. The lower overall accuracy was mainly due to the shortage of ground truth points. One advantage of using an unsupervised classification method is that it can be replicated on other reefs in the region.

The inherent absorption, scattering, and attenuation of radiance by the water column as captured by the sensor leads to a major error in the spectral reflectance of the objects which in turn may result in inappropriate classifications (Green et al., 2000). The empirical method from Lyzenga (1981) has been widely recommended to improve coral habitat zone classifications (Green et al., 2000) as applied in this study. However, experiments using Lyzenga's formula reported by Mumby et al. (1998) and Nurlidiasari (2004) on their work using ICAS and Quickbird satellite imagery showed improvement by only $13 \%$ and $20 \%$ respectively, indicating that applying Lyzenga's method would show minor significant improvement in classification accuracy. Consequently, the number of classes is principally constrained by the spectral and spatial resolution of the sensor utilized (Zainal et al., 1993).

The difficulty in distinguishing the reef crest and forereef slope environments is related to the narrow width of the reef slope dimension $(<30 \mathrm{~m})$ and the absence of a well-defined, highly reflective reef crest. Each pixel of a Landsat image represents approximately $900 \mathrm{~m} 2$ in the field, thus, any land feature less than such area is not mappable. A high-resolution image (1-10 $\mathrm{m}$ ground resolution) has been widely suggested by Joyce \& Phinn (2001) and Andréfouët et al. (2003) to optimally map reef environments. However, handdigitizing techniques are reliable to correct these 
misclassified pixels as applied in this study.

Another common limitation of using remote sensing images in reef mapping is that it is not easy to discriminate between live coral and other habitats that consist of chlorophyll organisms such as macroalgae and seagrass. The similarity in light spectra reflectance characteristics of these species can result in misclassifications. However, a manual editing process from Mumby et al., 1998 is suggested where habitat distributions are known. Despite these challenges, many reefs have been mapped successfully using remote sensing. This study has produced a detailed analysis of reef geomorphology and associated habitats, providing significant information on the distribution of reef according to type.

\section{CONCLUSION}

The Karimunjawa Islands have already been utilized for commercial activities such as marine tourism, fishing ground, aquaculture and port facilities, besides traditional use by the local people. Despite the fact that current uses have only resulted in limited anthropogenic disturbance, extensive marine tourism growth over the coming years will likely disrupt the marine environment considerably. This Landsat-based reef geomorphology and benthic habitats mapping provide a spatial framework for reef geomorphic and ecological studies at both regional (between reefs) and local (within reefs) scale. Such information gives a foundation for long-term coral reef studies, fisheries management and environmental monitoring that should be taken into consideration when planning and managing sustainable Karimunjawa marine and coastal resources. Some important management issues can be directed towards the basis of existing knowledge and some will require further work, including the history of reef formation and scientific research of predicting likely future environmental impacts in collaboration with survey design to inform management options.

\section{ACKOWLEDGEMENTS}

The authors would like to thank the director of Marine Research Center, Ministry of Marine Affairs and Fisheries, who has contributed a lot in supporting research activities in Marine Research Centre both financial and policy. The authors also thank valued members of Blue Carbon research group who have participated in ground truth and data collection. The paper is a contribution to local government, local people, and stakeholders who have authority in planning and managing the Karimunjawa marine and coastal regions. Tubagus Solihuddin is the main contributor of this article.

\section{REFFERENCE}

Ahmad, W., \& Neil, D.T. (1994). An evaluation of Landsat Thematic Mapper (TM) digital data for discriminating coral reef zonation: Heron Reef (GBR). International Journal of Remote Sensing, 15(13), 2583-2597.

Andréfouët, S., \& Muller-Karger, F. (2006). Global assessment of modern coral reef extent and diversity for regional science and management applications: a view from space. Proceedings of 10th International Coral Reef Symposium, Okinawa, Japan, 28 June-32nd July 2004, Japanese Coral Reef Society.

Andréfouët, S., Kramer, P., Torres-Pulliza, D., Joyce, K.E., Hochberg, E.J., Garza-Pérez, R., Mumby, P.J., Riegl, B., Yamano, H., White, W.H., Zubia, M., Brock, J.C., Phinn, S.R., Naseer, A., Hatcher, B.G., \& Muller-Karger, F. (2003). Multi-site evaluation of IKONOS data for classification of tropical coral reef environments. Remote Sensing of Environment, 88, 128-143.

Asriningrum, W. (2011). Reef morphology identification in Sikka, NTT using Landsat imagery. Journal of Indonesian Coral Reefs, 1, 48-54.

Van Bammelen, R.W. (1949). The Geology of Indonesia. Vol. LA: General Geology of Indonesia and Adjacent Archipelagoes. Martinus Nijhoff, The Hague, $723 \mathrm{pp}$.

Bina, R.T. (1982). Application of Landsat data to coral reef management in the Philippines, Proceedings of Great Barrier Reef Remote Sensing Workshop, Townsville, pp. 1-39.

Blanchon P. (2011). Geomorphic zonation. In: Hopley D. (ed.). Encyclopedia of modern coral reefs: structure, form and process. Dordrecht: Springer. 469-486.

Deshmukh, B., Bahuguna, A., Nayak, S., Dhargalkar, V.K., \& Jagtap, T.G. (2005). Eco-geomorphological zonation of the Bangaram reef, Lakshadweep. Photonirvachak, 33(1), 99-106.

Diaz, R.J., Solan, M., \& Valente, R.M. (2004). A review of approaches for classifying benthic habitats and evaluating habitat quality. Journal of Environmental Management, 73, 165e181.

Dunham, R.J. (1962). Classification of carbonate rocks according to depositional texture In: Ham, W. E. (Ed.), Classification of Carbonate Rocks. American Association of Petroleum Geologists, 
Memoir, 1, pp. 108-121.

Folk, R.L. (1954) The distinction between grain size and mineral composition in sedimentary-rock nomenclature. Journal of Geology, 62, 344-359.

Freeman, S.M., \& Rogers, S.I. (2003). A new analytical approach to the characterisation of macro-epibenthic habitats: linking species to the environment. Estuarine, Coastal and Shelf Science 56, 749e764.

Gischler, E., \& Lomando, A. J. (1999). Recent sedimentary facies of isolated carbonate platforms, Belize-Yucatan system, Central America. Journal of Sedimentary Research, 69, 747-763.

Gordon, L.A., Susanto, D.R., \& Vranes, K. (2003). Cool Indonesian throughflow as a consequence of restricted surface layer flow. Nature, 425, 824828.

Green, E.P., Mumby, P.J., \& Edwards, A.J. (2000). Remote Sensing Handbook for Tropical Coastal Management Sourcebooks, 3. UNESCO, Paris (316 pp. and plates).

Harris, P.M., \& Vlaswinkel, B. (2008). Modern isolated carbonate platforms: templates for quantifying facies attributes of hydrocarbon reservoirs. In: Lukasik, J., Simo, T. (Eds.), Controls on Carbonate Platform and Reef Development. SEPM Special Publication, 89, pp. 323-341.

Harris, P. M., Ellis, J., \& Purkis, S. (2010). Delineating and Quantifying Depositional Facies Patterns in Modern Carbonate Sand Deposits on Great Bahama Bank (SEPM Short Course Notes No. 54 p, paper p. 1-51, Appendix p. 1-31, and 2 DVDs).

Hopley, D., \& Partain, B. (1986). The structure and development of fringing reefs of the Great Barrier Reef Province, in: Baldwin, C. L., (Ed.), Fringing Reef Workshop: Science, Industry and Management. Great Barrier Reef Marine Park Authority, Townsville, pp. 13-33.

Hopley, D., Smithers, S.G., \& Parnell, K.E. (2007). The geomorphology of the Great Barrier Reef: development, diversity and change. Cambridge University Press, New York.

Joyce, K.E., \& Phinn, S.R. (2001). Optimal spatial resolution for coral reef mapping. Proceedings of the International Geoscience and Remote Sensing Symposium 2, 619-621.
Kaczmarek, S. E., Hicks, M. K., Fullmer, S. M., Steffen, K.L., \& Bachtel, S. L. (2010). Mapping facies distributions on modern carbonate platforms through integration of multispectral Landsat data, statistics-based unsupervised classifications, and surface sediment data. American Association of Petroleum Geologists Bulletin, 94, 1581-1606.

Kennedy, D.M., \& Woodroffe, C.D. (2002). Fringing reef growth and morphology: a review. Earth Science Review, 57, 255-277.

Kordi, M.N., \& O'Leary, M. (2016). A spatial approach to improve coastal bioregion management of the north Western Australia. Ocean \& Coastal Management, 127, 26-42.

Kuenen, Ph.H. (1933). Geology of coral reefs. The Snellius Expedition in the eastern part of the Netherlands East Indies 1929-1930. Vol. V, Geological Results, part 2. Kemink En Zoon N.V., Utrecht.

Kutser, T., Miller, I., \& Jupp, D.L.B. (2006). Mapping coral reef benthic substrates using hyperspectral space-borne images and spectral libraries. Estuarine. Coastal and Shelf Science, 70(3), 449460.

Luczkovich, J.J., Wagner, T.W., Michalek, J.L. \& Stoffle, R.W. (1993). Discrimination of coral reefs, seagrass meadows, and sand bottom types from space: a Dominican Republic case study. Photogrammetric Engineering and Remote Sensing, 59(3), 385-389.

Lyzenga, D.R. (1981). Remote sensing of bottom reflectance and water attenuation parameters in shallow water using aircraft and Landsat data. International Journal of Remote Sensing, 2, 7182.

Madden, R.H.C., Wilson, M.E.J., \& O'Shea, M. (2013). Modern fringing reef carbonates from equatorial SE Asia: An integrated environmental, sediment and satellite characterisation study. Marine Geology, 344, 163-185.

Maedar, J., Narumalani, S., Rundquist, D.C., Perk, R.L., Schalles, J., Hutchins, K., \& Keck, J. (2002). Classifying and mapping general coral-reef structure using IKONOS data. Photogrammetric Engineering and Remote Sensing, 68(12), 12971305.

Mazzullo, J., Graham, A. G., \& Braunstein, C. (1988). Handbook for Shipboard Sedimentologists. Ocean Drilling Program Technical Note No. 8. 
Montaggioni, L.F. (2005). History of Indo-Pacific coral reef systems since the last glaciation: development patterns and controlling factors. Earth Sci Rev, 71:1-75.

Mumby, P.J., Green, E.P., Clark, C.D., \& Edwards, A.J. (1998). Digital analysis of multispectral airborne imagery of coral reefs. Coral Reefs, 17, 59-69.

Nurlidiasari, M. (2004). The application of Quickbird and Multi-temporal Landsat TM data for coral reef habitat mapping. Case Study: Derawan Island, East Kalimantan, Indonesia. International Institute for Geo-Information Science and Earth Observation, Enschede, The Netheralnds.

Purkis, S.J., \& Pasterkamp, R. (2004). Integrating in situ reef-top reflectance spectra with Landsat TM imagery to aid shallow-tropical benthic habitat mapping. Coral Reefs, 23, 5-20.

Purkis, S.J., Riegl, B.M., \& Andréfouët, S. (2005). Remote sensing of geomorphology and facies on a modern carbonate ramp (Arabian Gulf, Dubai, U.A.E.). Journal of Sedimentary Research 75, 861-876.

Purkis, S.J., Harris, P.M., \& Ellis, J. (2012). Patterns of sedimentation in the contemporary Red Sea as an analog for ancient carbonates in rift settings. Journal of Sedimentary Research, 82(11), 859870.

Rankey, E.C. (2002). Spatial patterns of sediment accumulation on a Holocene carbonate tidal flat, northwest Andros Island, Bahamas. Journal of Sedimentary Research, 72(5), 591-601.

Riegl, B.M., Halfar, J., Purkis, S.J., \& Godinez-Ort, L. (2007). Sedimentary facies of the Eastern Pacific's northernmost reef-like setting (Cabo Pulmo, Mexico). Marine Geology, 236, 61-77.

Sanderson, P.G. (2001). The Application of Satellite Remote Sensing to Coastal Management in Singapore. AMBIO: A Journal of the Human Environment, 30(1), 43-48.

Sidarto., Santosa, S., \& Hermanto, B. (1993). Geological map of the Karimunjawa sheet, Jawa. Geological Research Centre, Bandung, Indonesia.

Solihuddin, T., Utami, A.D., Salim, H.L., \& Prihantono, J. (2019). Sedimentary Environment of A Modern Carbonate Platform of Karimunjawa Islands, Central Java. Indonesian Journal on Geoscience, 6(1), 57-72.
Tomascik, T., Mah, A.J., Nontji, A., \& Moosa, M.K. (1997). The ecology of Indonesian seas. Part 2, Periplus Editions.

Universitas Diponegoro, (1994). Pengelolaan terumbu karang di Kepulauan Karimunjawa, Kabupaten Dati II Jepara, Jawa Tengah: laporan akhir kegiatan penelitian perguruan tinggi. Semarang: Pusat Penelitian Energi dan Sumberdaya Alam, Lembaga Penelitian Universitas Diponegoro.

Veron, J.E.N. (2000). Corals of the world. Australian Institute of Marine Science 1-3, 1,382 pp.

Wyrtki, K. (1961). Physical Oceanography of the Southeast Asian Waters. Naga Report Vol. 2. Scripps Institution of Oceanography, La Jolla, California.

Zainal, A.J.M., Dalby, D.H., \& Robinson, I.S. (1993). Monitoring marine ecological changes on the east coast of Bahrain with Landsat TM. Photogrammetric Engineering and Remote Sensing, 59(3), 415-421. 
Reef Geomorphology and Associated Habitats ...... Small Islands Management (Solihuddin, T., et al.) 